\title{
Can Ramadan fasting cause relapse and aggravation of spontaneous intracranial hypotension?
}

\author{
Ramazan ayındaki açlık spontan intrakraniyal hipotansiyonda \\ nüks ve kötüleşmeye neden olabilir mi?
}

Sait ALBAYRAM,' Ayşegül GÜNDÜZ, ${ }^{2}$ Zehra IŞIK'

\begin{abstract}
or
Summary

Chronic headache is known to be aggravated by fasting and fasting even triggers headache among those not suffering from chronic headache. Headache is also aggravated during Ramadan in which Muslim people do not eat, drink, or smoke from dawn to sunset for about one month in a year. Headaches mainly increase in people who are prone to headaches like migraine sufferers. As far as we know there are no reports on specific headache syndromes pointing to precipitating factor of fasting. In this report, we present a 32-year-old man diagnosed with spontaneous intracranial hypotension, treated by conservative means and who relapsed after fasting during Ramadan. We aim to discuss the possible underlying mechanisms of precipitation of orthostatic headache during fasting.

Key words: Fasting; headache; month of Ramadan; spontaneous intracranial hypotension.
\end{abstract}

\section{Özet}

Kronik baş ăgrısının açlık ile kötüleştiği bilinmektedir ve açlık kronik baş ă̆rısı yaşamayan insanlarda dabi baş ağrısına neden olabilir. Baş ağrısı, Müslümanların yılda bir ay boyunca güneşin doğuşundan batışına kadar yemek yemediği, su ve sigara içmediği Ramazan ayı boyunca da kötüleşmektedir. Fakat bu ayda da özellikle migrenliler gibi baş ağrısına yatkın olan kişilerde baş ağrısı ortaya çıkmaktadır. Bildiğimiz kadarıyla açlık ile tetiklenen baş ağrısı sendromlarına işaret eden bildiri bulunmamaktadır. Burada, spontan intrakraniyal hipotansiyon tanısı konan, konservatif yöntemler ile tedavi edilen ve Ramazan ayı sırasındaki açlı ile tetiklenen baş ağrısı olan 32 yaşında bir olgu sunuldu; açlık nedeniyle tetiklenen ortostatik baş ağrısının olası mekanizmaları tartışıldı.

Anahtar sözcükler: Açlık; baş ağrısı; Ramazan; spontan intrakraniyal hipotansiyon.

\section{Introduction}

Chronic headache is known to be aggravated by fasting and fasting even triggers headache among those not suffering from chronic headache. ${ }^{[1]}$ Therefore, it is suggested to be a strong headache precipitator. Headache was also demonstrated to be aggravated during Ramadan ${ }^{[2]}$ which is the fasting month of the Moslem. But it mainly increases in people who are prone to headaches like migraine sufferrers. Intracranial hypotension is a syndrome characterized by orthostatic headache and low cerebrospinal fluid (CSF) pressure. It can be secondary to spinal/cranial surgery, lumbar puncture (LP) or dural damage due to spinal anesthesia; or can occur spontaneously without any trauma history. ${ }^{[3]}$ Spinal CSF leakage is the most common reason of spontaneous intracranial hypotension (SIH). As far as we know, there are no reports in this specific headache syndrome pointing to precipitating factor of fasting. In this report, we present a 32-year-old man diagnosed 
as $\mathrm{SIH}$, treated by conservative means and relapsed after fasting during Ramadan and we aim to discuss the possible underlying mechanisms.

\section{Case Report}

A 32-year-old man admitted to our outpatient clinic with severe orthostatic headache occurring in upright position and disappearing during supine position as well as tinnitus and instability. Neurological examination was normal except mild neck stiffness and mild ataxia. In history, there was no headache, but he declared intense sports activity four days before the development of the headache. Routine blood chemistry was normal. Gadolinium enhanced cranial magnetic resonance imaging (MRI) revealed bilateral dural thickening (Fig. 1). Orthostatic headache and cranial MRI findings were concordant with SIH syndrome. Since headache was severe and disrupted daily living activities, the patient was recommended to undergo epi-
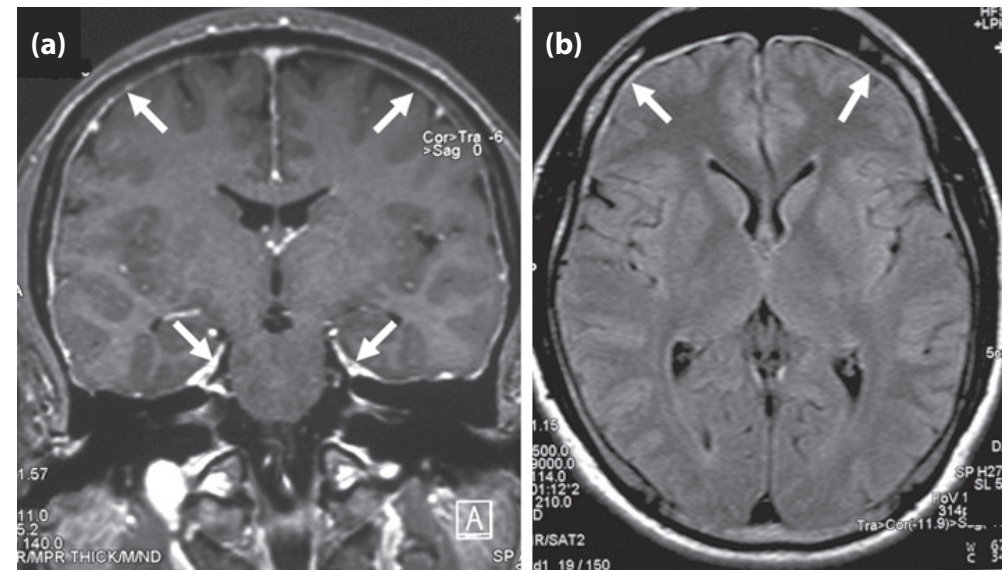

Fig. 1. (a) Gadolinium enhanced cranial MRI showing contrast enhancement and (b) FLAIR sequence showing bilateral dural thickening on admission.
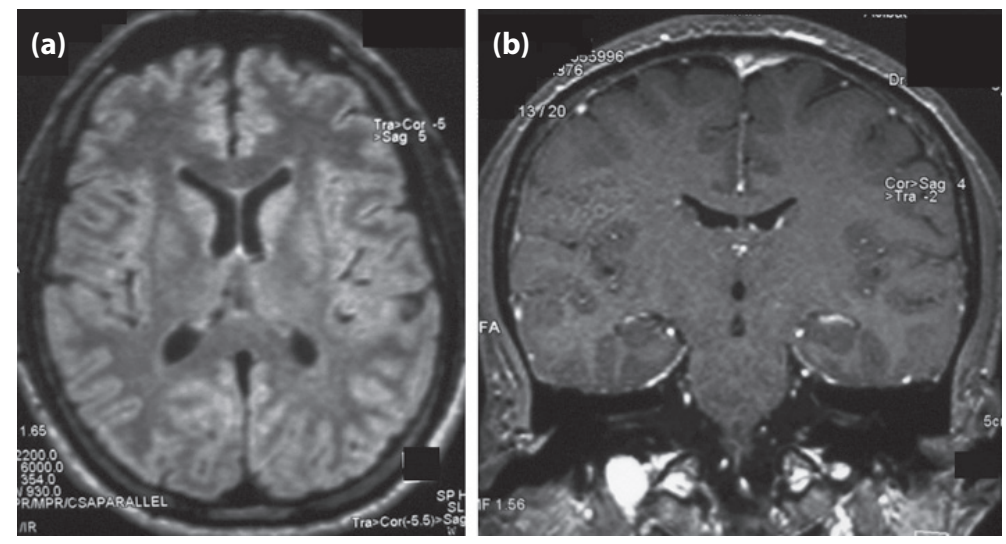

Fig. 2. (a) Neuroradiological improvement accompanying clinical improvement after 35 days of conservative treatment on both FLAIR and (b) gadolinium enhanced sequences. dural blood patch (EBP) application. However, he did not accept the procedure and therefore, he was recommended to rest in bed for ten days and to have increased amounts of fluid and caffeine. Following 10 days of conservative treatment orthostatic headache improved with only remaining mild nonorthostatic headache which was provoked by fasting and exhaustion and recovered with acetaminophen and caffeine. MRI at the end of 1 . month showed total improvement (Fig. 2) which continued for 6 months until the first half of Ramadan. After 2 weeks of fasting, severe orthostatic headache, neck pain and dizziness reappeared. He did not express any intense sports activity before the last episode. Since there were bilateral intense dural thickening and contrast enhancement on repeated cranial MRI (Fig. 3) and $10 \mathrm{~mm} \mathrm{H}_{2} \mathrm{O}$ opening pressure on LP, MR myelography was performed which revealed dural tear and CSF leakage at the cervico-dorsal level. Because the symptoms were severe and he had dural tear, we performed EBP with $25 \mathrm{cc}$ autologous blood at the level of C6-C7 cervical vertebra. Although he reported severe neck pain within the first 24 hours of EBP, headache improved totally in 1 to 2 days and subdural effusion disappeared radiologically after 15 days. In the 6 . month there existed no further clinical or radiological findings.

\section{Discussion}

Chronic recurrent headache may manifest as repeated exacerbations precipitated by many factors such as fasting, menstrual cycle, changes in sleep pattern, and certain foods in susceptible subjects. Studies which were carried out during some religious rituals proved the role of fasting in precipitation of headaches. There are reports of aggravation or appearance of headache in both chronic headache sufferers and nonsufferers during Yom Kippur headache of Jew or Ramadan of Moslems. ${ }^{[1,2]}$ The mechanisms in precipitation of headache by fasting are not totally established. However, dehydration, hypoglycemia, psychological and stress factors, accumulation of a me- 


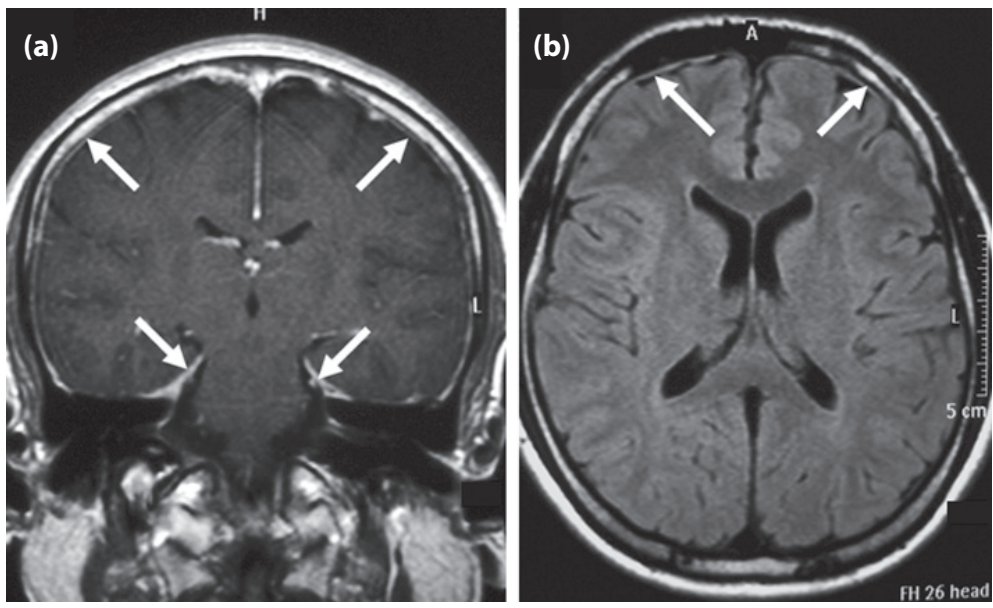

Fig. 3. Gadolinium enhanced (a) and FLAIR (b) sequences showing bilateral dural thickening and contrast enhancement after 2 weeks of fasting within the 6. month during the course of disease.

tabolite, withdrawal from habitual coffee and tea consumption, smoking and oversleeping are listed possible factors in precipitation of headaches during fasting. Peroutka ${ }^{[4]}$ proposed that the physiological maintenance of steady serum glucose levels, rather than the absolute level of serum glucose, may be responsible for initiating or exacerbating migraine and other types of headache in susceptible individuals. However, Mosek and Korczyn ${ }^{[1]}$ proposed that there existed no causal relationship between hypoglycemia and headache. Awada and Jumah ${ }^{[2]}$ denoted that coffee and tea consumption appeared to be a stronger risk factor for fasting related headache and caffeine withdrawal. Headache usually starts 12 to 24 hours after the cessation of caffeine-containing beverages and peaks at 20 to 48 hours which is compatible with the headache pattern. Commenting study of Mosek and Korczyn, Kundin ${ }^{[5]}$ reported that his Yom Kippur headache had characteristics similar to a postlumbar puncture headache and he concluded that thirst and/or caffeine withdrawal was responsible for this discomfort.

Clinical course and MRI findings of our patient suggested that conservative treatment provided clinical improvement allowing maintenance of daily living activities and working. However, following fasting, $\mathrm{SIH}$ symptoms relapsed acutely and severely and subdural effusion observed on cranial MRI suggested more severe clinical status during the relapse. The second SIH episode might be suggested as a seperate and distinct status which only coincided with the Ramadan. However it is worth noting that the conservative treatment may only lead to shrinkage of dural tear and compansatory mechanisms may provide clinical improvement resulting in improvement after the first episode whereas acute metabolic changes and dehydration during fasting and secondary decrease of CSF volume probably exceeded the boundaries of this compensation and orthostatic headache reemerged.

In conclusion, dural tear may only be partially healed by conservative treatment and continues subclinically. Despite clinical recovery or marked improvement, still a very low grade leak may continue and a mild and asymptomatic or minimally symptomatic CSF hypovolemia may be maintained. Since we know that any intrusive event leading to minor trauma may cause recurrence of headache, we may suggest that metabolic stress factors as dehydration during Ramadan may disrupt the compensatory mechanisms and trigger relapse or development of symptoms in SIH. Perhaps generalized hypovolemia associated with dehydration in connection with fasting can also be a contributory factor.

\section{References}

1. Mosek A, Korczyn AD. Yom Kippur headache. Neurology 1995;45(11):1953-5.

2. Awada A, al Jumah M. The first-of-Ramadan headache. Headache 1999;39(7):490-3.

3. Mokri B. Spontaneous low cerebrospinal pressure/volume headaches. Curr Neurol Neurosci Rep 2004;4(2):117-24.

4. Peroutka SJ. Serum glucose regulation and headache. Headache 2002;42(4):303-8.

5. Kundin JE. Yom Kippur headache. Neurology 1996;47(3):854. 